\title{
Efek Mediasi Kepuasan Pelanggan atas Pengaruh Kualitas Produk dan Store Atmosphere terhadap Loyalitas Pelanggan
}

\author{
Tjandra Gunawan ${ }^{1}$, Fathorrahman ${ }^{2 *}$, Yunus Handoko ${ }^{2}$ \\ ${ }^{1}$ PPS STIE ASIA Malang, Indonesia \\ ${ }^{2}$ Prodi Manajemen, STIE ASIA Malang, Indonesia \\ * faturrahman.asia.74@gmail.com
}

\begin{abstract}
The purposes of this study are :1) to determine the direct effect of product quality and store atmosphere on customer loyalt, 2) to determine the indirect effect of product quality and store atmosphere on customer loyalty through customer satisfaction as an intervening variable. This research is a field research with quantitative methods. The data collection uses a field survey method using a research instrument in the form of a questionnaire with a 5-points scale of likert. Population of this research are Vosco Coffee's customers. Samples taken are 150 customers selected by accidental-purposive sampling technique.. The results of path analysis reveal that: 1) directly, both product quality and store atmosphere have a positive and significant effect on customer loyalty; 2) customer satisfaction is also proven to be able to mediate the influence of product quality and store atmosphere on customer loyalty even though this indirect influence is not as big as direct influence.
\end{abstract}

Keywords: Culinary Business, Customer Loyalty, Customer Satisfaction, Product Quality, Store Atmosphere

\section{PENDAHULUAN}

Saat ini, negara-negara anggota Perserikatan Bangsa-Bangsa (PBB), termasuk Indonesia sudah memasuki era Sustainable Development Goals (SDGs), di mana dalam era ini pemerintah perlu mempersiapkan beberapa hal untuk memastikan pelaksanaan SDGs hingga tahun 2030. Prioritas agenda SDGs Indonesia adalah tercapainya pembangunan ekonomi yang berkelanjutan, baik di tingkat nasional maupun di tingkat daerah. Kota Malang merupakan salah satu daerah yang sedang mengalami peningkatan ekonomi sejak penurunan pertumbuhan ekonomi pada tahun 2013 silam. Pertumbuhan ekonomi Kota Malang tahun 2015 telah mencapai 5,61\% lebih tinggi dari provinsi Jawa Timur yang mencapai 5,56\%, bahkan lebih tinggi dari tingkat nasional yang sebesar 5,18 \% (Poerwanto, 2017). Pencapaian Kota Malang di bidang ekonomi terus meningkat. Ini dibuktikan oleh pendapatan Asli Daerah (PAD) kota Malang yang mengalami peningkatan dari tahun ke tahun dan tercatat di tahun 2015 sebesar Rp363 miliar, meningkat menjadi Rp387 miliar pada tahun 2016 dan pada tahun 2017 kembali meningkat ke angka Rp409 miliar (Politika Malang, 2017). Pencapaian ini masih akan terus meningkat seiring dengan perkembangan berbagai sektor yang berpengaruh seperti industri dan perdagangan serta yang berkembang paling pesat adalah sektor kuliner. 
Kuliner di Kota Malang telah mengalami patah tumbuh hilang berganti sejak tahun 2015. Fenomena ini ditunjukkan oleh bertumbuhnya kafe dan bisnis restoran yang lebih dari 100\% pada tahun 2016 (Miko, 2016). Demikian juga, menurut Indra Setiyadi, Ketua Apkrindo (Asosiasi Pengusaha Kafe dan Restoran Indonesia) Malang, terdapat 800 kafe telah didirikan dan dibuka di Kota Malang pada pertengahan 2016, dan pada akhir tahun 2016 jumlah tersebut sudah mencapai 1000 kafe (Radar Malang, 2017). Potensi positif ini dapat lebih cepat berkembang secara signifikan dengan dukungan infrastruktur dan pariwisata. Akan tetapi, pertumbuhan yang tidak terkendali di satu sektor tertentu, bisa menjadi ancaman bagi bisnis itu sendiri dalam bentuk situasi persaingan yang ketat di antara bisnis yang sejenis.

Strategi dalam menghadapi persaingan yang ketat ini antara lain adalah menciptakan strategi pemasaran yang berorientasi pada pelanggan yaitu suatu jenis pemasaran yang berfokus pada kepuasan kebutuhan dan keinginan pelanggan (McDonald dan Keegan, 1999). Pelanggan yang merasa puas akan melakukan pembelian berulang dan lama kelamaan akan menjadi pelanggan setia, sebagimana teori Kotler (2001) yang menyatakan bahwa pelanggan yang puas cenderung memiliki ikatan emosional dan loyalitas yang tinggi terhadap produk (Kotler, 2001).

Salah satu cara untuk melihat loyalitas pelanggan adalah dari kebiasaan pelanggan saat membeli produk, biasanya tanpa mempertimbangkan produk alternatif apa pun dari pesaing serta berkenan untuk merekomendasikan produk tersebut kepada teman-teman mereka (Mcllroy \& Barnett, 2000). Dengan demikian, dapat digeneralisasikan bahwa pelanggan yang loyal akan secara otomatis memberikan peluang bagi perusahaan untuk mendapatkan pelanggan baru. Selain itu, menurut Kotler (2006), mempertahankan semua pelanggan yang ada akan lebih menguntungkan daripada menggantinya. Ini dikarenakan biaya untuk mendapatkan pelanggan baru jauh lebih tinggi, bisa mencapai lima kalinya daripada mempertahankan pelanggan yang sudah ada. Jadi, loyalitas pelanggan sangat penting untuk pengembangan bisnis di masa depan. Perusahaan yang mampu mempertahankan loyalitas pelanggan akan memperoleh kesuksesan jangka panjang atas usaha yang dilakukan (Saputra, 2011).

Untuk mencapai loyalitas pelanggan yang tinggi, perusahaan harus memperhatikan faktor utama yang mempengaruhinya, yaitu kepuasan pelanggan (Khadka \& Maharjan, 2017). Sementara itu, penelitian Atiyah (2016) serta penelitian Razak (2016) mengungkap bahwa kualitas produk mempengaruhi kepuasan pelanggan. Sedangkan, Jalil (2016) dan Nurdiansyah \& Matadji (2016) juga menemukan bahwa kepuasan pelanggan dipengaruhi secara positif oleh store atmosphere. Hasil ini juga didukung oleh temuan Miswanto \& Angelia (2017). Di sisi lain, studi empiris yang dilakukan oleh Andini (2013) mengungkap bahwa baik kualitas produk, store atmosphere maupun kepuasan pelanggan berpengaruh positif dan signifikan terhadap loyalitas pelanggan.

Research gap terjadi pada penelitian Jahanshahi et al. (2011) yang menyatakan bahwa kualitas produk memiliki hubungan positif dengan kepuasan pelanggan dan kepuasan pelanggan sendiri berdampak positif terhadap loyalitas pelanggan, di mana kepuasan pelanggan berperan sebagi variabel intervening. Hasil penelitian ini didukung oleh penelitian Ukania (2017), menunjukkan bahwa kualitas produk berpengaruh baik secara langsung maupun tidak langsung terhadap loyalitas pelanggan. Pengaruh tidak langsung ini terjadi karena adanya mediasi kepuasan pelanggan. Produk yang berkualitas tinggi akan memuaskan pelanggan. Pelanggan yang merasa puas akan menimbulkan rasa nyaman dan bahagia apabila memakai produk atau jasa tersebut begitupun sebaliknya pelanggan yang tidak merasa puas akan menimbulkan rasa kecewa dan akan mencari produk atau jasa yang dirniliki perusahaan lain. 
Hasil penelitian Dabija dan Băbuţ (2014) juga mengungkap bahwa store atmosphere berpengaruh positif dan signifikan terhadap kepuasan pelanggan, dan kepuasan pelanggan sendiri juga berpengaruh positif dan signifikan terhadap loyalitas pelanggan. Dalam penelitian ini juga membuktikan adanya efek intervening variabel kepuasan pelanggan. Namun, research gap terjadi pada hasil penelitian Miswanto \& Angelia (2017) yang menunjukkan bahwa store atmosphere tidak berpengaruh terhadap kepuasan pelanggan. Research gap semakin terlihat pada hasil penelitian Claudia (2017) dimana hasil yang sangat kontradiksi ditunjukkan oleh tidak terbuktinya adanya pengaruh kualitas produk maupun store atmosphere terhadap kepuasan pelanggan, namun kepuasan pelanggan berpengaruh terhadap loyalitas pelanggan. Sehingga kepuasan pelanggan di sini tidak mampu memediasi hubungan kualitas produk dan store atmosphere terhadap loyalitas pelanggan.

Oleh karena itu, dalam penelitian ini akan membahas bagaimana pengaruh kualitas produk dan store atmosphere terhadap loyalitas pelanggan secara langsung maupun tidak langsung melalui kepuasan pelanggan, serta menguji apakah kepuasan pelanggan mampu memediasi pengaruh kualitas produk dan store atmosphere terhadap loyalitas pelanggan di Vosco Coffee Malang. Vosco Coffee merupakan salah satu kafe besar dan terkemuka di Kota Malang dengan produk utamanya berupa berbagai macam jenis kopi. Sebuah kafe yang secara non-formal disebut juga dengan kedai kopi ini menyajikan kopi panas, misalnya, café latte, cappuccino, espresso, teh, dan minuman panas lainnya. Kafe ini juga menyajikan minuman dingin seperti es kopi dan es teh. Selain itu, beberapa jenis makanan juga tersedia, seperti makanan ringan, muffin, atau kue kering. Kafe ini berdiri sejak bulan Maret 2012, di mana Hendi dan Ary, pemilik Kafe, mulai mengatur dan membuat tata letak untuk Vosco Coffee. Saat itu, bisnis ini hanya memiliki ekuitas kecil. Kedua saudara ini memiliki visi besar untuk bisnis ini. Mereka ingin kedai kopi ini diperluas dan menguntungkan. Uji coba tentang sesuatu yang baru dan mengembangkan beberapa produk adalah cara efektif untuk memunculkan pasar.

\section{Hipotesis}

Berdasarkan uraian beberapa penelitian yang relevan di atas maka hipotesis dalam penelitian ini adalah:

$\mathrm{H}_{1}$ : Diduga kualitas produk Vosco Coffee berpengaruh secara langsung terhadap loyalitas pelanggan

$\mathrm{H}_{2}$ : Diduga store atmosphere Vosco Coffee berpengaruh secara langsung terhadap loyalitas pelanggan

$\mathrm{H}_{3}$ : Diduga kepuasan pelanggan Vosco Coffee berpengaruh secara langsung terhadap loyalitas pelanggan

$\mathrm{H}_{4}$ : Diduga kualitas produk Vosco Coffee berpengaruh secara tidak langsung terhadap loyalitas pelanggan melalui kepuasan pelanggan

$\mathrm{H}_{5}$ : Diduga store atmosphere Vosco Coffee berpengaruh secara tidak langsung terhadap loyalitas pelanggan melalui kepuasan pelanggan

\section{METODE}

\section{Pendekatan Penelitian}

Sesuai dengan permasalahan yang di uraikan pada latar belakang, penelitian ini merupakan field research dengan menggunakan pendekatan kuantitatif. Dalam penelitian ini persepsi responden tentang variabel-variabel penelitian, yaitu: kualitas produk, store atmosphere, kepuasan pelanggan dan loyalitas pelanggan dikuantitatifkan dengan skala likert 5 poin, dari sangat tidak setuju sampai sangat setuju, sehingga data yang diperoleh merupakan data kuantitatif.

\section{Metode Pengambilan Sampel}

Populasi dari penelitian ini tidak diketahui jumlahnya karena pelanggan yang hadir berkunjung tidak dapat diprediksi jumlahnya, bisa berubah sewaktu-waktu. Sehingga pengambilan sampel dilakukan 
dengan metode accidental-purposive sampling yang merupakan bagian dari nonprobability sampling. Accidental sampling adalah teknik pengambilan sampel secara kebetulan. Jadi, siapa atau apa saja yang kebetulan bertemu dengan peneliti dapat digunakan sebagai sampel bila dinilai cocok sebagai sumber data (Sujarweni, 2015). Sedangkan purposive sampling adalah penentuan sampel berdasarkan pertimbangan tertentu. Jadi accidental-purposive sampling yang digunakan dalam penelitian ini adalah teknik pengambilan sampel penelitian dengan cara menemukan responden yang merupakan pelanggan Vosco Coffee Malang secara kebetulan karena responden sedang berada dalam kedai dan peneliti juga sedang mencari responden dalam kedai, namun responden tersebut memiliki kriteria yang menjadi pertimbangan peneliti, antara lain: 1) bersedia menjadi responden, 2) minimal telah 3x (tiga kali) melakukan transaksi atau pembelian produk Vosco Coffee, dan 3) dapat memberikan informasi yang dibutuhkan dalam penelitian melalui kuisioner. Jumlah sampel yang diambil dalam penelitian ini adalah 150 responden. Hal ini mengacu pendapat Roscoe (1975) yang menyatakan bahwa ukuran sampel lebih dari 30 dan kurang dari 500 adalah tepat untuk kebanyakan penelitian.

\section{Metode Analisis Data}

Metode analisis data dalam penelitian ini menggunakan analisis jalur (Path Analysis). Analisis jalur adalah suatu teknik untuk mengestimasi dampak dari serangkaian variabel terikat terhadap sebuah variabel bebas dari serangkaian hubungan (korelasi) yang teramati, di mana diduga terdapat hubungan sebab akibat asimetris di antara variabel tersebut. Model ini biasanya digunakan untuk menjelaskan pola hubungan antar variabel dengan tujuan mengetahui pengaruh langsung maupun tidak langsung dari seperangkat variabel bebas (eksogen) terhadap variabel terikat (endogen). Dalam analisis ini mengandung variabel intervening.

Variabel intervening adalah variabel yang secara teoritis mempengaruhi hubungan antara variabel independen dengan variabel dependen menjadi hubungan yang tidak langsung dan tidak diamati dan diukur. Adapun model penelitian analisis jalur adalah sebagai berikut:

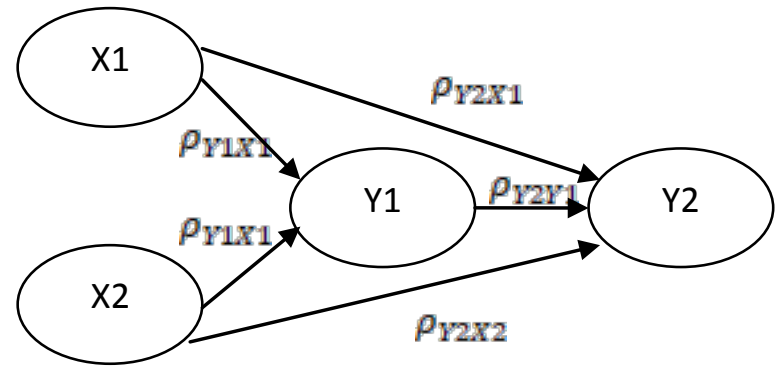

Gambar 1. Model Jalur

Model jalur pada gambar 1 di atas merupakan salah satu contoh model penelitian yang menggunakan analisis jalur. Dalam gambar tersebut, terdapat dua variabel independen yaitu X1 dan X2, sedangkan Y2 adalah variabel dependen, sementara Y1 adalah variabel intervening.

\section{HASIL DAN PEMBAHASAN Karakteristik Responden}

Karakteristik responden ditinjau berdasarkan usia, pendidikan, jenis kelamin, pendapatan dan pekerjaan responden disajikan dalam tabel 1 berikut:

Tabel 1. Data Responden

\begin{tabular}{lcc}
\hline $\begin{array}{c}\text { Karakteristik } \\
\text { Responden }\end{array}$ & Jumlah & Persentase \\
\hline < 21 tahun & Usia \\
$21-25$ tahun & 24 & 16,0 \\
$26-30$ tahun & 32 & 38,0 \\
$31-35$ tahun & 17 & 11,3 \\
$36-40$ tahun & 10 & 6,6 \\
$41-45$ tahun & 8 & 5,4 \\
$46-50$ tahun & 2 & 1,3 \\
\hline Total & 150 \\
\hline \multicolumn{3}{c}{ Pendidikan } \\
\hline Diploma dan & 116 \\
Sarjana (S1) & 34 & 77,3 \\
Magister (S2) & 150 \\
\hline Total & Jenis Kelamin \\
\hline \multicolumn{3}{c}{93} \\
\hline Laki-Laki & 57 & 62,0 \\
Perempuan &
\end{tabular}




\begin{tabular}{|c|c|c|}
\hline Total & 150 & 100,0 \\
\hline \multicolumn{3}{|c|}{ Pendapatan } \\
\hline$<$ Rp 2,5 juta & 49 & 32,7 \\
\hline $\begin{array}{l}\text { Rp 2,5 juta - Rp } 5 \\
\text { juta }\end{array}$ & 63 & 42,0 \\
\hline $\begin{array}{l}\text { Rp } 5 \text { juta - Rp 7,5 } \\
\text { juta }\end{array}$ & 28 & 18,7 \\
\hline$>$ Rp 7,5 juta & 10 & 6,7 \\
\hline Total & 150 & 100,0 \\
\hline \multicolumn{3}{|c|}{ Pekerjaan/ aktivitas } \\
\hline $\begin{array}{l}\text { Pelajar atau } \\
\text { Mahasiswa }\end{array}$ & 57 & 38,0 \\
\hline $\begin{array}{l}\text { Pekerja atau } \\
\text { Pengusaha }\end{array}$ & 52 & 34,7 \\
\hline $\begin{array}{l}\text { Pelajar atau } \\
\text { Mahasiswa } \\
\text { sekaligus Pekerja } \\
\text { atau Pengusaha }\end{array}$ & 41 & 27,3 \\
\hline Total & 150 & 100,0 \\
\hline
\end{tabular}

Sumber: data diolah

Berdasarkan hasil analisis deskriptif kelima karakteristik responden pada tabel 1, diketahui bahwa sebagian besar pelanggan berusia 21 tahun sampai 25 tahun, berpendidikan atau sedang menempuh pendidikan diploma dan sarjana, berjenis kelamin laki-laki, memiliki penghasilan $\mathrm{Rp}$ 2,5 juta sampai Rp5 juta per bulan, sedang memiliki kesibukan sebagai pelajar atau mahasiswa. Intinya karakteristik responden penelitian ini adalah kalangan muda, khususnya mahasiswa yang mendominasi pelanggan Vosco Coffee Malang.

\section{Uji Instrumen Penelitian \\ Uji Validitas}

Hasil uji validitas setiap variabel penelitian disajikan dalam Tabel 2 berikut.

Tabel 2. Hasil Uji Validitas

\begin{tabular}{|c|c|c|c|c|c|}
\hline Variabel & R-hitung & R-tabel & Sig. & $\alpha$ & Hasil \\
\hline Kualitas Produk &, $922^{* *}$ & \multirow{4}{*}{0,1603} & 0 & \multirow{3}{*}{0,05} & Valid \\
\hline Store Atmosphere & $941^{* *}$ & & 0 & & Valid \\
\hline Kepuasan Pelanggan &, $704^{* *}$ & & 0 & & Valid \\
\hline Loyalitas Pelanggan & $941^{* *}$ & & 0 & & Valid \\
\hline
\end{tabular}

Sumber: data diolah

Berdasarkan tabel 2 hasil uji validitas, diketahui bahwa nilai R-hitung kualitas produk sebesar 0,922 > R-tabel sebesar 0,1603 dengan Sig. sebesar 0,000 < 0,05.
Nilai R-hitung variabel store atmosphere sebesar 0,941 > R-tabel sebesar 0,1603 dengan Sig. sebesar 0,000 $<0,005$. Nilai Rhitung kepuasan pelanggan sebesar 0,704 > R-tabel sebesar 0,1603 dengan Sig. sebesar $0,000<0,05$. Demikian juga dengan nilai Rhitung variabel loyalitas pelanggan sebesar 0,941 > R-tabel sebesar 0,1603 dengan Sig. sebesar 0,000 < 0,05. Karena nilai R-hitung semua variabel lebih besar dari R-tabel dan Sig. lebih kecil dari taraf signifikansi 5\% $(0,05)$, maka kuisioner yang digunakan sebagai instrumen penelitian untuk mengukur setiap variabel-variabel penelitian adalah valid atau sah.

\section{Uji Reliabilitas}

Hasil uji reliabilitas setiap variabel penelitian disajikan dalam tabel 3 berikut.

Tabel 3. Hasil Uji Reliabilitas

\begin{tabular}{lrcl}
\hline \multicolumn{1}{c}{ Variabel } & $\begin{array}{c}\text { Cronbach's } \\
\text { Alpha if } \\
\text { Item }\end{array}$ & $\begin{array}{c}\text { Ketentuan } \\
\text { Batas Nilai }\end{array}$ & Kesimpulan \\
\hline Kualitas Produk & 0,795 & $>0,6$ & Reliabel \\
Store Atmosphere & 0,838 & $>0,6$ & Reliabel \\
Kepuasan Pelanggan & 0,914 & $>0,6$ & Reliabel \\
Loyalitas Pelanggan & 0,786 & $>0,6$ & Reliabel \\
\hline
\end{tabular}

Sumber: data diolah

Berdasarkan tabel 3 hasil uji reliabilitas, diketahui bahwa nilai Cronbach's Alpha variabel kualitas produk sebesar 0,795, variabel store atmosphere sebesar 0,838, variabel kepuasan pelanggan sebesar 0,914 dan variabel loyalitas pelanggan sebesar 0,786 kesemuanya lebih besar dari 0,6. Ini menunjukkan bahwa instrumen atau kuisioner yang digunakan untuk mengukur variabel-variabel penelitian adalah reliabel atau handal.

\section{Analisis Jalur (Path Analysis)}

Analisis jalur adalah suatu teknik untuk mengestimasi dampak dari serangkaian variabel bebas terhadap sebuah variabel bebas dari serangkaian hubungan (korelasi) yang teramati, dimana diduga terdapat hubungan sebab akibat asimetris di antara variabel tersebut. Model ini biasanya digunakan untuk menjelaskan pola hubungan 
antar variabel dengan tujuan mengetahui pengaruh langsung maupun tidak langsung dari seperangkat variabel bebas (eksogen) terhadap variabel terikat (endogen). Dalam analisis ini biasanya melibatkan variabel intervening. Variabel intervening adalah variabel yang secara teoritis mempengaruhi hubungan antara variabel independen dengan variabel dependen menjadi hubungan yang tidak langsung. Adapun variabel bebas (eksogen) dalam penelitian ini adalah kualitas produk dan store atmosphere, variabel terikat (endogen) adalah loyalitas pelanggan, sedangkan variabel intervening yang akan diuji peran mediasinya adalah kepuasan pelanggan. Sehingga, dalam analisis jalur akan dilakukan dua kali regresi, yaitu regresi tahap I: regresi variabel kualitas produk dan store atmosphere terhadap kepuasan pelanggan dan regresi tahap II: regresi variabel kualitas produk, store atmosphere dan kepuasan pelanggan terhadap loyalitas pelanggan.

\section{Regresi Tahap I}

Berikut adalah hasil analisis regresi tahap I, yaitu regresi variabel kualitas produk dan store atmosphere terhadap kepuasan pelanggan. Berdasarkan tabel 4, diketahui bahwa nilai R-Square sebesar 0,352. Artinya, hanya 35,2\% kepuasan pelanggan Vosco Coffee dijelaskan oleh kualitas produk dan store atmosphere. Sedangkan 64,8\% dijelaskan oleh variabel-variabel lain yang tidak digunakan dalam penelitian ini, seperti kualitas layanan, harga, promosi, lokasi, dan lain-lain.

Tabel 4. Hasil Uji Determinasi Regresi Tahap I

\begin{tabular}{|c|c|c|c|c|}
\hline Model & $\mathrm{R}$ & R Square & $\begin{array}{l}\text { Adjusted R } \\
\text { Square }\end{array}$ & $\begin{array}{l}\text { Std. Error } \\
\text { of the } \\
\text { Estimate }\end{array}$ \\
\hline 1 &, $593^{\mathrm{a}}$ & ,352 & ,343 & 1,033 \\
\hline
\end{tabular}

Tabel 5. Hasil Uji F Regresi Tahap I

\begin{tabular}{rrrcccc}
\hline \multirow{2}{*}{ Model } & $\begin{array}{c}\text { Sum of } \\
\text { Squares }\end{array}$ & df & $\begin{array}{c}\text { Mean } \\
\text { Square }\end{array}$ & F & Sig. \\
\hline 1 & Regression & 85,122 & 2 & 42,561 & 39,888 &, $000^{\mathrm{b}}$ \\
& Residual & 156,852 & 147 & 1,067 & & \\
& Total & 241,973 & 149 & & & \\
\hline
\end{tabular}

a. Dependent Variable: Kepuasan Pelanggan

b. Predictors: (Constant), Store Atmosphere, Kualitas Produk Sumber: data diolah

Berdasarkan tabel 5 hasil Uji F diketahui nilai F-hitung sebesar 39,888 dengan Sig. sebesar 0,000. Sementara F-tabel untuk $\alpha=0,05, \quad d f_{1}=2$, dan $d f_{2}=147$ sebesar 3,057621. Ini menunjukkan bahwa Fhitung $>$ dari F-tabel dengan Sig. kurang dari 0,05 . Artinya, model jalur yang terbentuk memenuhi goodness of fit model sehingga layak digunakan untuk memprediksi kepuasan pelanggan Vosco Coffee. Adapun model jalur yang terbentuk berdasarkan nilai B (konstanta) dan nilai Beta (Standardized Coefficient) dalam tabel 6 adalah $Y_{1}=0,457+0,351 X_{1}+0,273 X_{2}+\varepsilon$.

Tabel 6. Koefisien Jalur dan Hasil Uji t Regresi Tahap I

\begin{tabular}{|c|c|c|c|c|c|c|}
\hline \multirow[t]{2}{*}{ Model } & & \multicolumn{2}{|c|}{$\begin{array}{l}\text { Unstandardized } \\
\text { Coefficients }\end{array}$} & \multirow{2}{*}{$\begin{array}{c}\text { Standardized } \\
\text { Coefficients } \\
\text { Beta }\end{array}$} & \multirow[t]{2}{*}{$\mathrm{t}$} & \multirow[t]{2}{*}{ Sig. } \\
\hline & & $\mathrm{B}$ & Std. Error & & & \\
\hline \multirow{3}{*}{1} & (Constant) & 0,457 & 2,842 & & 0,161 & 0,873 \\
\hline & Kualitas Produk & 0,155 & 0,05 & 0,351 & 3,136 & 0,002 \\
\hline & $\begin{array}{r}\text { Store } \\
\text { Atmosphere }\end{array}$ & 0,088 & 0,036 & 0,273 & 2,442 & 0,016 \\
\hline
\end{tabular}

Sumber: data diolah

Berdasarkan tabel 6 di atas, diketahui bahwa nilai t-hitung variabel kualitas produk sebesar 3,136 dengan Sig. sebesar 0,02, sedangkan t-hitung variabel store atmosphere sebesar 2,442 dengan Sig. sebesar 0,16. Sementara nilai t-tabel untuk $\alpha=0,05$ dan $d f=147$ sebesar 1,976233. Ini menunjukkan bahwa nilai t-hitung variabel kualitas produk tidak berada dalam rentang -t-tabel (1,976233) sampai +t-tabel $(1,976233)$ dan Sig. < 0,05. Artinya, kualitas produk berpengaruh positif dan signifikan terhadap kepuasan pelanggan. Demikian juga dengan nilai t-hitung variabel store atmosphere tidak berada dalam rentang -t-tabel $(-1,976233)$ sampai +t-tabel $(1,976233)$ dan Sig. < 0,05. Artinya, store atmosphere berpengaruh 
positif dan signifikan terhadap kepuasan pelanggan.

\section{Regresi Tahap II}

Berikut adalah hasil analisis regresi tahap II, yaitu regresi variabel kualitas produk, store atmosphere, dan kepuasan pelanggan terhadap loyalitas pelanggan. Berdasarkan tabel 7, diketahui bahwa nilai RSquare sebesar 0,806. Artinya, hanya 80,6\% loyalitas pelanggan Vosco Coffee dijelaskan oleh kualitas produk, store atmosphere dan kepuasan pelanggan. Sedangkan 19,4\% dijelaskan oleh variabel-variabel lain yang tidak dipertimbangkan dalam penelitian ini. Variabel-variabel tersebut dapat berupa kualitas layanan, harga, promosi, lokasi, strategi marketing, brand image, dan lainlain.

Tabel 7. Hasil Uji Determinasi Regresi Tahap II

\begin{tabular}{lcccc} 
Model & R & R Square & $\begin{array}{c}\text { Adjusted R } \\
\text { Square }\end{array}$ & $\begin{array}{c}\text { Std. Error } \\
\text { of the } \\
\text { Estimate }\end{array}$ \\
\hline 1 &, $898^{\mathrm{a}}$ & $\mathbf{, 8 0 6}$ &, 802 & 1,130 \\
\hline
\end{tabular}

a. Predictors: (Constant), Kepuasan Pelanggan, Store

Atmosphere, Kualitas Produk

Sumber: data diolah

Tabel 8. Hasil Uji F Regresi Tahap II

\begin{tabular}{|c|c|c|c|c|c|c|}
\hline Mode & & $\begin{array}{l}\text { Sum of } \\
\text { Squares }\end{array}$ & $\mathrm{df}$ & $\begin{array}{c}\text { Mean } \\
\text { Square }\end{array}$ & $\mathrm{F}$ & Sig. \\
\hline \multirow{3}{*}{1} & Regression & 774,253 & 3 & 258,084 & 201,95 &, $000^{\mathrm{b}}$ \\
\hline & Residual & 186,581 & 146 & 1,278 & & \\
\hline & Total & 960,833 & 149 & & & \\
\hline
\end{tabular}

a. Dependent Variable: Loyalitas Pelanggan

b. Predictors: (Constant), Kepuasan Pelanggan, Store

Atmosphere, Kualitas Produk

Sumber: data diolah

Berdasarkan tabel 8 hasil Uji F diketahui nilai F-hitung sebesar 201,952 dengan Sig. sebesar 0,000. Sementara F-tabel untuk $\alpha=0,05, \quad d f_{1}=2, \quad$ dan $\quad d f_{2}=147$ sebesar 2,666574. Ini menunjukkan bahwa Fhitung $>$ dari F-tabel dengan Sig. kurang dari 0,05 . Artinya, model jalur yang terbentuk memenuhi goodness of fit model sehingga layak digunakan untuk memprediksi loyalitas pelanggan Vosco Coffee. Adapun model jalur yang terbentuk berdasarkan nilai B (konstanta) dan nilai Beta (Standardized Coefficient) dalam tabel 9 adalah:

\section{$Y_{2}=-24,947+0,383 X_{1}+0,402 X_{2}+$ $0,225 Y_{1}+\varepsilon$}

Tabel 9. Koefisien Jalur dan Hasil Uji t Regresi Tahap II

\begin{tabular}{lcccccc}
\multirow{2}{*}{ Model } & \multicolumn{2}{c}{$\begin{array}{c}\text { Unstandardized } \\
\text { Coefficients }\end{array}$} & $\begin{array}{c}\text { Standardized } \\
\text { Coefficients }\end{array}$ & $\mathrm{t}$ & Sig. Kesimpulan \\
\cline { 2 - 4 } & $\mathrm{B}$ & Std. Error & Beta & & & \\
\hline $\begin{array}{c}\text { (Constant) } \\
\text { Kualitas }\end{array}$ & $\mathbf{- 2 4 , 9 5}$ & 3,11 & & $-8,02$ & 0 & Signifikan \\
$\begin{array}{l}\text { Produk } \\
\begin{array}{l}\text { Store } \\
\text { Atmosphere }\end{array}\end{array}$ & 0,338 & 0,056 & $\mathbf{0 , 3 8 3}$ & 6,04 & 0 & Signifikan \\
$\begin{array}{l}\text { Kepuasan } \\
\text { Pelanggan }\end{array}$ & 0,449 & 0,04 & $\mathbf{0 , 4 0 2}$ & 6,41 & 0 & Signifikan \\
\hline
\end{tabular}

a. Dependent Variable: Loyalitas Pelanggan

Sumber: data diolah

Berdasarkan tabel 9 di atas, diketahui bahwa nilai t-hitung variabel kualitas produk sebesar 6,040 dengan Sig. sebesar 0,000, sedangkan t-hitung variabel store atmosphere sebesar 6,410 dengan Sig. sebesar 0,000. Sementara nilai t-tabel untuk $\alpha=0,05$ dan $d f=146$ sebesar 1,976346. Ini menunjukkan bahwa nilai t-hitung variabel kualitas produk tidak berada dalam rentang -t-tabel (1,976346) sampai +t-tabel $(1,976346)$ dan Sig.< 0,05. Artinya, kualitas produk berpengaruh positif dan signifikan terhadap loyalitas pelanggan. Demikian juga dengan nilai t-hitung variabel store atmosphere tidak berada dalam rentang - t-tabel $(-1,976346)$ sampai + t-tabel $(1,976346)$ dan Sig. $<0,05$. Artinya, store atmosphere berpengaruh positif dan signifikan terhadap loyalitas pelanggan. Nilai t-hitung variabel kepuasan pelanggan tidak berada dalam rentang -ttabel $(-1,976346)$ sampai + t-tabel $(1,976346)$ dan Sig. < 0,05. Artinya, kepuasan pelanggan berpengaruh positif dan signifikan terhadap loyalitas pelanggan.

\section{Hasil Analisis Jalur dan Sobel Test}

Berikut disajikan hasil analisis jalur berdasarkan hasil regresi dua tahap sebelumnya, juga disajikan hasil Sobel test untuk menguji apakah kepuasan pelanggan memang mampu memediasi pengaruh kualitas produk dan store atmosphere terhadap loyalitas pelanggan, atau dengan kata lain, untuk menguji apakah kepuasan 
pelanggan memang berperan sebagai variabel intervening.

Tabel 10. Hasil Analisis Jalur Jalur dan Sobel Test

\begin{tabular}{lrr}
\hline \multicolumn{1}{c}{ Model } & $\mathrm{X} 1 \rightarrow \mathrm{Y} 1 \rightarrow \mathrm{Y} 2$ & $\mathrm{X} 2 \rightarrow \mathrm{Y} 1 \rightarrow \mathrm{Y} 2$ \\
\hline Pengaruh Langsung & 0,383 & 0,402 \\
Pengaruh Tidak Langsung & $0,351^{*} 0,225=0,079$ & $0,273 * 0,225=0,061$ \\
Pengaruh Total & 0,462 & 0,463 \\
Sobel Test & 2,35511284 & 2,37430445 \\
Z-Score $\alpha=0,05$ & 1,96 & 1,96 \\
\hline \multicolumn{1}{c}{ Kesimpulan } & Y1 Mediator & Y1 Mediator \\
& (Variabel Intervening) & (Variabel Intervening) \\
\hline
\end{tabular}

Sumber: data diolah

Berdasarkan tabel 10 di atas, diketahui bahwa pengaruh langsung kualitas produk terhadap loyalitas pelanggan sebesar 0,383 lebih besar dari pengaruh tidak langsung kualitas produk terhadap loyalitas pelanggan melalui kepuasan pelanggan sebagai mediator yang sebesar 0,079. Sedangkan pengaruh total kualitas produk terhadap loyalitas pelanggan sebesar 0,462. Adapun hasil kalkulasi nilai sobel seperti yang ditunjukkan dalam gambar 2 hasil screenshoot sobel test online sebesar 2,35511284 lebih besar dari nilai Z-score untuk $\alpha=0,05$ yang sebesar 1,96. Ini menunjukkan bahwa kepuasan pelanggan mampu memediasi pengaruh kualitas produk terhadap loyalitas pelanggan, atau, dengan kata lain, kepuasan pelanggan adalah variabel intervening atau mediator pengaruh tidak langsung kualitas produk terhadap loyalitas pelanggan.

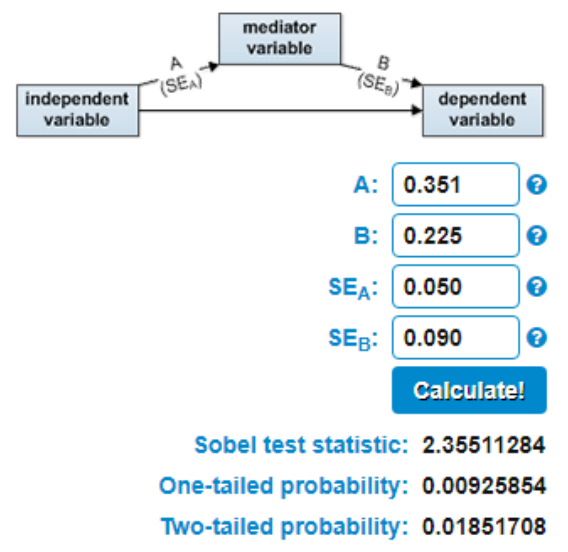

Gambar 2. Hasil Screenshoot Sobel Test Online Sumber: data diolah $\mathrm{X} 1 \rightarrow \mathrm{Y} 1 \rightarrow \mathrm{Y} 2$

https://www.danielsoper.com/statcalc/calculator.aspx? $\underline{\mathrm{id}=31}$ (2018)

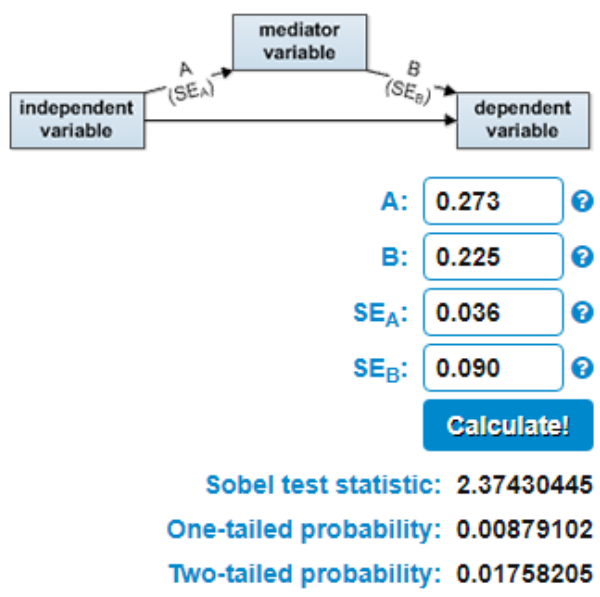

Gambar 3. Hasil Screenshoot Sobel Test Online $\mathrm{X} 2 \rightarrow \mathrm{Y} 1 \rightarrow \mathrm{Y} 2$

Sumber: data diolah

https://www.danielsoper.com/statcalc/calculator.aspx? $\underline{\mathrm{id}=31}$ (2018)

Berdasarkan tabel 10 di atas, juga diketahui bahwa pengaruh langsung store atmosphere terhadap loyalitas pelanggan sebesar 0,402 lebih besar dari pengaruh tidak langsung store atmosphere terhadap loyalitas pelanggan melalui kepuasan pelanggan sebagai mediator yang sebesar 0,061. Sedangkan pengaruh total store atmosphere terhadap loyalitas pelanggan sebesar 0,463. Adapun hasil kalkulasi nilai sobel seperti yang ditunjukkan dalam gambar 3 hasil screenshoot sobel test online sebesar 2,37430445 lebih besar dari nilai Z-score untuk $\alpha=0,05$ yang sebesar 1,96 . Ini menunjukkan bahwa kepuasan pelanggan mampu memediasi pengaruh store atmosphere terhadap loyalitas pelanggan, atau, dengan kata lain, kepuasan pelanggan adalah variabel intervening atau mediator pengaruh tidak langsung store atmosphere terhadap loyalitas pelanggan.

Berdasarkan analisis di atas, maka dapat ditarik ihtisar penerimaan atau penolakan hipotesis penelitian seperti yang tersaji dalam Tabel 11, di mana kelima hipotesis penelitian diterima. 
Tabel 11. Ikhtisar Hasil Analisis (Penolakan/Penerimaan Hipotesis)

\begin{tabular}{|c|c|c|}
\hline & Hipotesis & $\begin{array}{l}\text { Ditolak/ } \\
\text { Diterima }\end{array}$ \\
\hline H1 & $\begin{array}{l}\text { Kualitas produk Vosco Coffee } \\
\text { berpengaruh secara langsung, positif } \\
\text { dan signifikan terhadap loyalitas } \\
\text { pelanggan }\end{array}$ & Diterima \\
\hline $\mathrm{H} 2$ & $\begin{array}{l}\text { Store atmosphere Vosco Coffee } \\
\text { berpengaruh secara langsung, positif } \\
\text { dan signifikan terhadap loyalitas } \\
\text { pelanggan }\end{array}$ & Diterima \\
\hline H3 & $\begin{array}{l}\text { Kepuasan pelanggan Vosco Coffee } \\
\text { berpengaruh secara langsung, positif } \\
\text { dan signifikan terhadap loyalitas } \\
\text { pelanggan }\end{array}$ & Diterima \\
\hline H4 & $\begin{array}{l}\text { Kualitas produk Vosco Coffee } \\
\text { berpengaruh secara tidak langsung } \\
\text { terhadap loyalitas pelanggan melalui } \\
\text { kepuasan pelanggan sebagai } \\
\text { mediator atau variabel intervening }\end{array}$ & Diterima \\
\hline H5 & $\begin{array}{l}\text { Store atmosphere Vosco Coffee } \\
\text { berpengaruh secara tidak langsung } \\
\text { terhadap loyalitas pelanggan melalui } \\
\text { kepuasan pelanggan sebagai } \\
\text { mediator atau variabel intervening }\end{array}$ & Diterima \\
\hline
\end{tabular}

\section{Pembahasan}

Berdasarkan hasil analisis jalur, diketahui variabel kulitas produk dan store atmosphere Vosco Coffee Malang berpengaruh langsung secara positif dan signifikan terhadap loyalitas pelanggan, juga berpengaruh secara tidak langsung terhadap loyalitas pelanggan melalui kepuasan pelanggan. Sedemikian hingga, jika manajer atau owner Vosco Coffee ingin meningkatkan loyalitas pelanggan secara signifikan agar usaha dapat terus bertahan menghadapi persaingan bisnis kuliner yang semakin ketat di Kota Malang, maka pihak manajer atau owner Vosco Coffee Malang seharusnya meningkatkan kepuasan pelanggan, kualitas produk dan store atmosphere.

Teori Kotler (2006) menyebutkan bahwa mempertahankan pelanggan yang ada akan lebih menguntungkan daripada menggantinya, ini dikarenakan biaya untuk menarik pelanggan baru bisa lima kali lipat dari biaya yang dibutuhkan untuk mempertahankan pelanggan yang sudah ada. Jadi, disamping berupaya mencari pelanggan baru, akan lebih baik pula berfokus pada mempertahankan atau jika memungkinkan meningkatkan loyalitas pelanggan yang sudah ada, yaitu dengan cara meningkatkan kualitas produk, store atmosphere dan antesenden kepuasan pelanggan lainnya. Semakin banyak pelanggan yang loyal dapat memberikan kontribusi yang positif terhadap perkembangan kafe. Pelanggan yang setia biasanya berencana untuk datang kembali, bersedia membayar lebih untuk layanan yang lebih, mendukung orang lain yang ingin datang ke Vosco Cofee, memberi tahu orang lain tentang citra positif Vosco Coffee dari mulut ke mulut (word of mouth) dan bersedia merekomendasikan orang lain untuk berkunjung atau bertemu di kafe ini. Jadi, pelanggan setia bisa menjadi media promosi gratis bagi kafe, karena mereka bersedia membawa pelanggan baru untuk menjadi pelanggan Vosco Cofee.

\section{Pengaruh Kualitas Produk terhadap Loyalitas Pelanggan}

Berdasarkan hasil analisis data, diketahui variabel kualitas produk berpengaruh secara langsung, positif dan signifikan terhadap loyalitas pelanggan. Temuan ini konsisten dengan penelitian sebelumnya, terutama penelitian Jahanshahi et al. (2011) dan Andini (2013) yang meneliti pelanggan perusahaan otomotif di India. Jika ditelaah berdasarkan analisis deskriptif, pengaruh kualitas produk terhadap loyalitas pelanggan sangat kuat, dapat dikarenakan karena rata-rata responden adalah kaum muda, laki-laki, yang memiliki income cukup untuk mendukung mereka "nongkrong" di kafe bersama teman-teman mereka, khususnya mereka yang masih mahasiswa. Kaum muda masa kini cukup selektif dalam memilih produk, apalagi didukung dengan finansial yang mereka miliki, sehingga kualitas produk menjadi salah satu tuntutan mereka. Saat ini juga marak start-up bisnis. Banyak kaum muda yang sedang menjalankan bisnis start-up membutuhkan tempat elegan semacam kafe untuk bertemu dan berdiskusi dengan para relasi dan klien. Kualitas produk yang disajikan kafe tentu akan mempengaruhi mood mereka dalam berbincang dan berdiskusi. Sehingga kualitas produk tetap menjadi tuntutan bagi mereka, 
dan jika terpenuhi akan berdampak pada loyalitas.

Loyalitas pelanggan bagi Vosco Coffee merupakan faktor yang paling penting dalam usaha mempertahankan sebuah kafe di tengah persaingan yang semakin ketat akibat semakin menjamurnya bisnis kuliner di Kota Malang. Jika tidak, para pelanggan akan beralih ke kafe kompetitor. Ini berakibat pada menurunnya jumlah pelanggan dan income kafe yang juga berdampak pada profitabilitas usaha. Jika tidak terkendali, dampaknya buruk, kafe dapat gulung tikar. Kejadian seperti ini sudah banyak terjadi di banyak kafe di Kota Malang. Pelanggan yang loyal akan akan memiliki niat untuk datang kembali ke kafe tersebut, sendiri, bersama keluarga, teman atau koleganya, bahkan mereka akan menceritakan hal-hal positif tentang Vosco Coffee bahkan mendorong orang lain untuk datang, merekomendasikan kepada orang-orang yang sedang membutuhkan kafe, bahkan bersedian membayar lebih untuk layanan prima yang diberikan kafe.

Jadi, untuk meningkatkan loyalitas pelanggan, kualitas produk harus dipertahankan, bahkan lebih baik jika ditingkatkan. Ada 8 dimensi yang menentukan kualitas produk menurut Tjiptono (2007), antara lain: kinerja, fitur, keandalan produk (itu berbeda dengan keandalan layanan), kesesuaian, daya tahan dan kemudahan servis. Jadi, untuk meningkatkan kualitas produk, manajemen Vosco Coffee perlu meningkatkan 8 dimensi kualitas produk, di antaranya adalah: 1) meningkatkan penampilan produk agar lebih menarik sekalipun rata-rata pelanggan yang menjadi responden sudah menilai tinggi penampilan produk, namun masih ada sekitar 2,7\% yang menilai buruk. Ini dimungkinkan yang menilai adalah responden dengan income dan pendidikan tinggi yang menuntut penampilan produk sesuai dengan kelas mereka; 2) meningkatkan fitur produk, ratarata pelanggan yang menjadi responden penelitian tidak memberikan nilai yang tinggi, artinya masih banyak potensi untuk meningkatkan fitur produk agar pelanggan lebih loyal; 3) meningkatkan keandalan produk karena masih ada pelanggan yang menjadi responden menilai keandalan produk Vosco Coffee sangat rendah; 4) membuat produk sesuai kebutuhan pelanggan karena masih ada pelanggan yang menjadi responden menyatakan bahwa produk masih belum sesuai dengan kebutuhan pelanggan, mungkin memberikan angket isian kepada setiap pelanggan yang datang untuk mengutarakan produk yang seperti apa yang dibutuhkan menjadi solusi yang mudah dalam menghadapi kasus ini, kemudian harapan mana yang memungkinkan untuk disediakan Vosco Coffee; 5) meningkatkan daya tahan produk tetapi tanpa penggunaan pengawet buatan; 6) menyajikan produk yang mudah diproses sehingga layanan dapat dilakukan dengan cepat; 7) memberikan produk yang unik atau memiliki nilai estetika; dan 8) meningkatkan kualitas rasa produk sesuai selera pelanggan.

\section{Pegaruh Store Atmosphere terhadap Loyalitas Pelanggan}

Variabel independen kedua yang mempengaruhi loyalitas pelanggan secara langsung, positif dan signifikan adalah store atmosphere. Temuan ini mendukung hasil penelitian Purba (2016), Hussain \& Ali (2015) dan penelitian Andini (2013) yang menemukan bahwa store atmosphere berpengaruh positif dan signifikan terhadap loyalitas pelanggan. Namun tidak mendukung temuan Dabija \& Băbuţ (2014) yang mengungkap bahwa pengaruh store atmosphere tidak berpengaruh signifikan terhadap loyalitas pelanggan perusahaan ritel. Ini dikarenakan pada perusahaan ritel pelanggan tidak perlu stay lama dalam toko, mereka hanya datang untuk membeli barang eceran, sekalipun barang tersebut berupa makanan. Produk makanan yang telah dibeli, tidak dimakan di toko, melainkan dibawa pulang. Sementara pada Vosco Coffee yang merupakai kafe atau kedai, sebagian besar pelanggan membeli makanan dan minuman untuk dikonsumsi di lokasi. Sehingga, suasana kafe akan mempengaruhi loyalitas mereka. 
Jika ditelah berdasarkan analisis deskriptif, store atmosphere tentu sangat mempengaruhi loyalitas pelanggan, karena sebagian besar responden adalah kalangan muda, mahasiswa dengan uang saku atau income yang berkecukupan. Tren selfie/wefie di sebuah kafe untuk diupload di media sosial, sekalipun hanya berkumpul untuk "nongkrong", entah dalam rangka berdiskusi sambil mengerjakan tugas kampus, atau sekedar berbincang santai dengan para sahabat, menjadikan kalangan mudah selektif dalam memilih kafe. Kafe yang memiliki atmosfer bagus menjadi tujuan utama mereka.

Menurut Berman dan Evans (1995), store atmosphere dapat dibagi menjadi beberapa elemen utama: eksterior, interior umum, tata letak dan tampilan toko, di mana setiap elemen memiliki banyak indikator. Karena store atmosphere juga merupakan variabel yang berdampak positif dan signifikan terhadap loyalitas pelanggan, maka manajer Vosco Coffee harus memperbaiki kondisi atmosfer toko/kafe. Hal ini dapat dilakukan dengan meningkatkan kebersihan secara keseluruhan, baik lantai kafe, rak (display cabinet, meja dan kursi), memutar musik yang mampu membuat pelanggan menjadi rileks dan mampu menghasilkan keinginan pelanggan untuk menambah layanan atau membeli produk, musik yang membuat lingkungan sangat menyenangkan dengan ritme yang tepat sehingga pelanggan nyaman berada lama dalam kafe, volume musik juga pas di telinga pelanggan.

Selain itu, aroma kafe juga merupakan elemen penting yang harus diperhatikan. Manajemen harus dapat memilih aroma terapi yang memicu pelanggan untuk membeli lebih banyak produk dan membuat pelanggan merasa ingin tinggal lebih lama dalam kafe, dan bahkan ingin kembali ke kafe di lain waktu. Kualitas AC (air conditioner) juga tidak bisa diabaikan. AC dengan tingkat dingin sesuai dengan tubuh pelanggan dapat membuat pelanggan merasa nyaman berada dalam kafe.
Penting bagi manajemen kafe untuk mengatur pencahayaan di kafe, baik itu perbedaan frekuensi cahaya dan perbedaan warna. Pencahayaan yang pas di mata membuat pelanggan dapat melihat produk atau menu dengan jelas, pelanggan dapat mengevaluasi kualitas produk benda-benda yang ada dalam kafe, dan produk terlihat menjadi lebih menarik sehingga membuat pelanggan merasa senang. Pencahayaan yang tepat juga tidak akan maksimal tanpa diimbangi warna kafe yang bagus dan menarik. Pemilihan warna kafe sangat penting karena dapat memicu citra dan persepsi positif di benak pelanggan. Suasana toko tidak akan lepas dari pengaruh tampilan yang menarik dan mengesankan. Sebanyak mungkin informasi yang cukup tentang kafe dan berbagai produk tersedia, bisa dalam bentuk buku menu, buku informasi kafe atau katalog. Tampilan informasi juga harus diatur agar pelanggan dapat melihat menu atau produk dengan jelas dan kritis. Daftar produk atau menu yang sistematis dan kreatif juga harus disiapkan untuk memudahkan pelanggan dalam memilih pesanan.

Berdasarkan analisis frekuensi jawaban responden pada angket penelitian, beberapa item yang harus diutamakan untuk di tingkatkan karena masih banyak pelanggan yang menjadi responden menilai cukup rendah, antara lain: 1) kebersihan lantai kafe, 2) musik yang dapat menciptakan suasana santai, 3) kualitas AC, 4) pencahayaan di gerai agar lebih pas di mata.

\section{Pengaruh Kepuasan Pelanggan terhadap Loyalitas Pelanggan}

Berdasarkan hasil analisis diketahui variabel kepuasan pelanggan berpengaruh secara langsung, positif dan signifikan terhadap loyalitas pelanggan. Temuan ini mendukung beberapa penelitian sebelumnya, seperti penelitian Khadka dan Maharjan (2017), Ukania (2017), Claudia (2017), Kusuma et al. (2014), Dabija \& Băbuţ (2014), Andini (2013) dan Jahanshahi et al. (2011). Kepuasan pelanggan merupakan perasaan senang atau kecewa seseorang yang timbul karena membandingkan kinerja yang 
dipersepsikan produk (atau hasil) terhadap ekspentasi mereka Kotler (2009). Responden penelitian ini sebagian besar adalah kalangan muda. Kalangan muda di zaman ini memiliki harapan yang tinggi atas setiap hal, termasuk terhadap produk-produk yang dikonsumsinya. Harapan yang terpenuhi akan ditunjukkan dalam bentuk kepuasan yang pada akhirnya mengarah pada loyalitas mereka terhadap produk tersebut. Jika tidak ada keluhan terhadap produk Vosco Coffee yang mereka konsumsi, senang dengan semua produk yang tersaji, layanan yang diberikan juga sesuai ekspektasi mereka, bahkan ekspektasi mereka terlampaui, maka dapat dipastikan mereka akan memiliki niat untuk berkunjung kembali dan merekomendasikan Vosco Coffee kepada para teman dna relasi mereka.

Jika ditelaah berdasarkan analisis frekuensi jawaban responden terhadap pernyataan-pernyataan yang ada dalam kuisioner, Vosco Coffee harus meningkatkan kepuasan pelanggan karena masih banyak yang menilai bahwa kepuasan yang mereka dapatkan masih kurang, walau secara ratarata sudah merasa puas. Adapun yang dapat dilakukan oleh pihak manajemen Vosco Coffee untuk meningkatkan kepuasan pelanggan adalah meminimalisir keluhan yang pernah ada. Setiap keluhan yang ada dicatat, diperbaiki dan dievaluasi. Setiap personil juga harus cepat tanggap terhadap setiap keluhan pelanggan. Selain itu, kuisioner isian atau instrumen, bisa dalam bentuk call centre, WA, email, yang dapat menampung keluhan, saran dan kritik dari pelanggan juga harus tersedia. Dengan demikian, pihak manajemen akan tahu apa keinginan pelanggan dan apa yang harus dilakukan untuk perbaikan, sehingga pelanggan menjadi puas saat mengkonsumsi produk-produk Vosco Coffee dan semakin loyal.

\section{Kualitas Produk, Kepuasan dan Loyalitas Pelanggan}

Hasil penelitian ini menunjukkan bahwa kualitas produk berpengaruh baik secara langsung maupun tidak langsung terhadap loyalitas pelanggan, yaitu melalui kepuasan pelanggan. Penelitian ini mendukung hasil penelitian Jahanshahi et al. (2011), Kusuma et al. (2014) dan Ukania (2017) yang telah membuktikan bahwa kualitas produk berdampak positif terhadap kepuasan pelanggan, sedangkan kepuasan pelanggan berdampak positif terhadap loyalitas pelanggan. Terungkap pula bahwa kepuasan pelanggan mampu memediasi dampak kualitas produk terhadap loyalitas pelanggan. Ini sesuai dengan hasil penelitian Khadka \& Maharjan (2017) yang menjelaskan bahwa untuk mencapai loyalitas pelanggan yang tinggi, perusahaan harus memperhatikan faktor utama yang mempengaruhinya, yaitu kepuasan pelanggan. Sedangkan kepuasan pelanggan, menurut hasil temuan Atiyah (2016) dan Razak (2016), dipengaruhi secara signifikan oleh kualitas produk.

Pengaruh langsung kualitas produk terhadap loyalitas pelanggan, dalam penelitian ini, ditemukan lebih besar daripada pengaruh tidak langsung kualitas produk terhadap loyalitas pelanggan melalui kepuasan pelanggan. Sedangkan kepuasan pelanggan terhadap loyalitas pelanggan sangat kuat, bahkan lebih kuat dibandingkan kualitas produk. Ini menunjukkan bahwa manajemen Vosco Coffee, bagimanapun, harus mempertimbangkan faktor-faktor lain yang mempengaruhi kepuasan pelanggan dan berusaha meningkatkannya. Ini dapat berupa tingkat harga bersaing, differensiasi produk, kualitas layanan, penguatan brand image dan brand love, promosi, dan lain-lain.

Produk yang berkualitas di mana produk tersebut memiliki kinerja tinggi, fitur bagus, handal, sesuai, memiliki daya tahan tinggi, mudah pelayanannya, memiliki estetika dan preceived quality menjadikan pelanggan tidak memiliki keluahan tetapi justri senang mengkonsumsi produk tersebut, apalagi jika sesuai dengan harapan bahkan melampaui harapan mereka. Ini akan menjadikan para pelanggan memiliki niat kuat untuk datang kembali ke kafe tersebut, baik untuk kepentingan yang sama atau berbeda, pelanggan juga berkenan untuk 
membayar lebih atas pelayanan prima yang mereka dapatkan, mau mendorong orang lain untuk datang ke kafe, secara otomatis melakukan positive words of mouth dan merekomendasikan kafe tersebut kepada orang lain.

\section{Store Atmosphere, Kepuasan dan Loyalitas Pelanggan}

Hasil penelitian ini menunjukkan bahwa store atmosphere berpengaruh baik secara langsung maupun tidak langsung terhadap loyalitas pelanggan, yaitu melalui kepuasan pelanggan. Hasil ini memang mendukung temuan Purba (2016) yang mengungkap bahwa store atmosphere berpengaruh langsung secara positif terhadap loyalitas pelanggan. Juga, mendukung hasil temuan Andini (2013), Jalil (2016) dan Nurdiansyah (2017) yang menjelaskan bahwa store atmosphere berpengaruh positif dan signifikan terhadap kepuasan pelanggan. Namun, hasil penelitian ini kotradiksi dengan hasil temuan Miswanto \& Angelia (2017) dan Andini (2013) yang mengungkap bahwa store atmosphere tidak berpengaruh terhadap kepuasan pelanggan.

Hasil temuan ini juga menunjukkan bahwa pengaruh langsung store atmosphere terhadap loyalitas pelanggan lebih tinggi daripada pengaruh tidak langsung. Hasil ini juga kontradiksi dengan hasil temuan Dabija \& Băbuţ (2014) yang mengungkap bahwa pengaruh langsung store atmosphere terhadap loyalitas pelanggan tidak signifikan atau, dengan kata lain, pengaruh tidak langsung store atmosphere terhadap loyalitas pelanggan melalui kepuasan pelanggan justru lebih tinggi daripada pengaruh langsungnya. Ini menunjukkan bahwa penelitian ini cenderung lebih sejalan dengan hasil temuan Claudia (2017) yang mengungkap bahwa store atmosphere tidak berpengaruh terhadap kepuasan pelanggan, namun pengaruh kepuasan pelanggan terhadap loyalitas pelanggan positif signifikan. Jika niat pembelian ulang merupakan bagian dari perilaku loyalitas pelanggan, maka penelitian ini mendukung penelitian Hussain \& Ali (2015). Namun secara lebih mendalam, penelitian Hussain \& Ali menyatakan bahwa kebersihan, aroma, pencahayaan dan tampilan atau tata letak adalah antesenden store atmospher yang paling berdampak pada loyalitas pelanggan. Sementara musik dan warna tidak berdampak signifikan, dan suhu hampir tidak berdampak pada loyalitas pelanggan.

Terungkap pula dalam penelitian ini bahwa kepuasan pelanggan mampu memediasi dampak store atmosphere terhadap loyalitas pelanggan. Hasil ini mendukung sepenuhnya hasil penelitian Dabija \& Băbuţ (2014), walau secara langsung, hubungan store atmosphere dengan loyalitas pelanggan tidak signifikan. Adapun hasil penelitian Claudia (2017) walau menggunakan kepuasan dan loyalitas pelanggan sebagai variabel dependen, namun dalam penelitian tersebut tidak menguji dampak intervening dari kepuasan pelanggan.

Walau pengaruh langsung store atmosphere dalam penelitian ini ditemukan lebih kuat daripada pengaruh tidak langsung melalui kepuasan pelanggan, namun, tetap penting bagi manajemen Vosco Coffee untuk meningkatkan kepuasan pelanggan, mengingat bahwa pengaruh kepuasan pelanggan begitu kuat terhadap loyalitas pelanggan. Empat hal yang menjadi indikator kepuasan pelanggan, dua di antaranya yang sangat nyata adalah dapat diukur melalui keluhan dan perasaan bahagia mereka saat berada dalam kafe dan mengkonsumsi produk. Jika pelanggan tidak ada yang mengeluhkan masalah kebersihan, musik, aroma, temperatur, pencahayaan, warna, dan display dan raut muka mereka menunjukkan rasa senang, maka dapat dipastikan bahwa kepuasan pelanggan tercapai. Walau demikian, untuk meningkatkan loyalitas pelanggan di tengah persingan ketat bisnis kuliner di Kota Malang, sebaik nya pihak manajemen Vosco Coffee tetap terus memperhatikan store atmosphere, yang terdiri dari 5 bagian utama, yaitu: kebersihan, musik, aroma, temperatur dan pencahayaan, warna dan display. Adapun hal-hal yang perlu diperhatikan secara details adalah 
kebersihan lantai kafe, kebersihan rak-rak, peralatan dan perlengkapan, jenis dan volume musik, aroma ruangan kafe, kualitas AC, pencahayaan yang tepat, tidak terlalu menyilaukan juga tidak terlalu redup, atau ada tempat-tempat tertentu yang memang sedikit dibuat redup untuk nuansa romantik, kombinasi dan corak warna dinding, lantai, plafon, atap dan lain-lain serta display yang teratur, rapi dan menarik.

\section{Kesimpulan}

Berdasarkan hasil analisis dan pembahasan, maka dapat ditarik kesimpulan sebagai berikut: 1) Kualitas produk Vosco Coffee memiliki dampak yang sangat besar terhadap loyalitas pelanggan, 2) Store atmosphere Vosco Coffee memiliki dampak yang sangat besar terhadap loyalitas pelanggan, 3) Kepuasan pelanggan Vosco Coffee memiliki dampak yang sangat besar terhadap loyalitas pelanggan, 4) Kepuasan pelanggan mampu memediasi dampak kualitas produk Vosco Coffee terhadap loyalitas pelanggan, 5) Kepuasan pelanggan mampu memediasi dampak store atmosphere Vosco Coffee terhadap loyalitas pelanggan.

\section{DAFTAR PUSTAKA}

Andini, Putri Farah. (2013). Analisis Pengaruh Suasana Toko, Kualitas Produk, dan Kepuasan Pelanggan Terhadap Loyalitas Pelanggan (Studi pada Konsumen Distro Deep Store di Surakarta), Skripsi, Program Sarjana Fakultas Ekonomi dan Bisnis Universitas Diponegoro, Semarang, diunduh dari http://eprints.undip.ac.id/42131/1/AND INI.pdf pada tanggal 5 Januari 2018.

Arikunto, Suharsimi (2006). Prosedur Penelitian Suatu Pendekatan Praktik, Rineka Cipta, Jakarta.

Atiyah, Latif. (2016). Product's Quality And Its Impact On Customer Satisfaction A Field Study In Diwaniyah Dairy Factory, Proceedings of The 10th International Management Conference "Challenges Of Modern Management", November 3rd-4th, 2016, Bucharest,
Romania, pp. 57-65, Diunduh Dari Http://Conferinta.Management.Ase.Ro/ Archives/2016/Pdf/1_7.Pdf, Pada Tanggal 15 Januari 2018.

Berman, Barry and Evans Joel R.. (1995). Retail Management: A Strategic Approach, 6th Edition, Prentice-Hall. Inc., Englewood Cliffs, New Jersey.

Claudia, Maria. (2017). Analisis Pengaruh Harga, Suasana Toko, Kualitas Produk, dan Kualitas Layanan terhadap Loyalitas Pelanggan melalui Kepuasan Pelanggan, Skripsi, Program Studi Manajemen, Fakultas Ekonomi, Universitas Sanata Dharma, Yogyakarta, diunduh dari https://repository.usd.ac.id/17774/2/13 2214138_full.pdf pada tanggal 15 Januari 2018.

Dabija, Dan-Cristian dan Raluca Băbuţ. (2014). Enhancing Consumers' Satisfaction And Loyalty Of Retailers In Romania Through Store Ambiance And Communication, Procedia Economics and Finance Journal, Vol. 15, 371-382. doi: 10.1016/S22125671(14)00459-6, diunduh dari https://core.ac.uk/download/pdf/82713 101.pdf pada tanggal 15 Januari 2018, tersedia online di www.elseiver.com/locate/prosedia dan www.sciencedirect.com.

Hussain, Riaz and Mazhar Ali. ( 2015). Effect of Store Atmosphere on Consumer Purchase Intention, International Journal of Marketing Studies; Vol. 7, No. 2 35-43, doi:10.5539/ijms.v7n2p35, diunduh dari https://mpra.ub.unimuenchen.de/72707/1/MPRA_paper_7 2707.pdf pada tanggal 5 Januari 2018.

Jahanshahi, Asghar Afshar, Mohammad Ali Hajizadeh Gashti, Seyed Abbas Mirdamadi, Khaled Nawaser, Seyed Mohammad Sadeq Khaksar. (2011), Study the Effects of Customer Service and Product Quality on Customer Satisfaction and Loyalty, International Journal of Humanities and Social Science, Vol. 1 No. 7, 253-260, 
diunduh

dari

http://www.ijhssnet.com/journals/Vol.

1_No. 7_[Special_Issue June_2011]/3

3.pdf, pada tanggal 6 Januari 2018.

Jalil, Nur Aina Abdul, Amily Fikry, Anizah Zainuddin. (2016). The Impact Of Store Atmospherics, Perceived Value, and Customer Satisfaction on Behavioural Intention, Fifth International Conference on Marketing and Retailing (5th Incomar) 2015, Procedia Economics and Finance, 37, 538 - 544, doi: 10.1016/S22125671(16)30162-9, diunduh dari https://core.ac.uk/download/pdf/82325 298.pdf pada tanggal 5 Januari 2018, tersedia online di www.elseiver.com/locate/procedia dan www.sciencedirect.com.

Khadka, Kabu \& Soniya Maharjan. (2017). Customer Satisfaction And Customer Loyalty, Case Trivsel Städtjänster (Trivsel Siivouspalvelut), Thesis, Business Management, Centria University of Applied Sciences Pietarsaari, diunduh dari https://www.theseus.fi/bitstream/handle 10024/139650/khadka_kabu\%20\%20a nd\%20\%20maharjan_\%20soniya.pdf?s equence $=1$ pada tanggal 3 April 2018.

Kotler, Philip. (2001). Dasar-Dasar Pemasaran, Edisi Kesembilan, Jilid I. Indeks. Jakarta.

Kotler, Philip. (2006). Manajemen Pemasaran, Edisi 11, Indeks, Jakarta.

Kotler, Philip, 2009, Manajemen Pemasaran, Edisi 13, Erlangga, Jakarta.

Kusuma, Nanda Primidya, Imam Suyadi dan Yusri Abdillah. (2014). Analyzing the Effect of Product Quality on Customer Satisfaction and Customer Loyalty in Indonesian SME's (Case Study on the Customer of Batik Bojonegoro Marely Jaya), Jurnal Administrasi Bisnis (JAB), Vol. 14, No. 1, hal.1 - 7, diunduh dari http://administrasibisnis.studentjournal. ub.ac.id/index.php/jab/article/view/574 pada tanggal 9 Januari 2018.
McDonald, H.B. Malcolm dan Warren J. Keegan. (1999). Marketing Plans That Work, Edisi I, Erlangga, Jakarta.

Mcllroy, Andrea and Shirley Barnett. (2000). Building Customer Relationship: Do Discount Cards Work? Managing Service Quality, International Journal, Vol. 10, Issue: 6. pp. 347 - 355.

Miko. (2016). Bisnis Makanan Tumbuh Menggeliat. downloaded from: http://radarmalang.co.id/bisnismakanan-tumbuh-menggeliat34157.htm, on February 2017.

Miswanto dan Yessi Ria Angelia, 2017, The Influence Of Service Quality And Store Atmosphere On Customer Satisfaction, Jurnal Manajemen Dan Kewirausahaan (Jmk), Vol. 19, No. 2, 106-111 Doi: 10.9744/Jmk.19.2.106-111, Issn 14111438 Print / Issn 2338-8234 Online, Diunduh

Dari

Http://Jurnalmanajemen.Petra.Ac.Id/In dex.Php/Man/Article/View/20393/1931 5 Pada Tanggal 14 Februari 2018.

Nurdiansyah, Muhammad Demas Nurdiansyah dan Matadji. (2016). Pengaruh Kualitas Layanan, Harga dan Atmosfer Toko Terhadap Kepuasan Pelanggan Toko Buku Togamas Gajah Mada Sidoarjo, Jurnal Ekonomi Manajemen, Volume 1, Nomor 1, Hal 29 - 44, diunduh Dari Http://Jurnal.Untag-

Sby.Ac.Id/Index.Php/Jem17/Article/Do wnload/663/596 pada Tanggal 5 Januari 2018.

Poerwanto, Endy. (2017). Pertumbuhan Ekonomi di Malang Dipacu Pariwisata, downloaded from: http://bisniswisata.co.id/2017pertumbuhan-ekonomi-di-malangdipacu-pariwisata/ on 13 Februari 2017.

Politika Malang. (2017). Kaleidoskop 2017: Pencapaian kota Malang dalam Bidang Ekonomi, diunduh dari http://politikamalang.com/pencapaiankota-malamg-dalam-bidang-ekonomi/ pada tanggal 3 Januari 2018. 
Purba, Septi Suhendra. (2016). Pengaruh Store Atmosphere Terhadap Loyalitas Pelanggan (Studi Kasus pada Black White Centro Tea and Coffee Bar Jalan Setia Budi Square Blok C No. 7 Komp. Tasbi 1), Skripsi, Program Studi Ilmu Admnisitrasi Bisnis, Fakultas Ilmu Sosial dan Ilmu Politik, Universitas Sumatera Utara, Medan, diunduh dari http://repositori.usu.ac.id/bitstream/han dle/123456789/2772/120907140.pdf?se quence $=1$ pada tanggal 15 Januari 2018.

Radar Malang. (2017). Ini Prospek Bisnis Cafe di Kota Malang, downloaded from:

http://radarmalang.jawapos.com/read/2 017/02/13/3147/ini-prospek-bisniscafe-di-kota-malang- on 13 Februari 2017.

Razak, Ismail. (2016). The Impact of Product Quality and Price on Customer Satisfaction with the Mediator of Customer Value, Journal of Marketing and Consumer Research, Vol.30, 5968, diunduh dari https://www.iiste.org/vol-30-2016journal-of-marketing-and-consumerresearch/ pada tanggal 18 Januari 2018.

Roscoe, J. T.. (1975). Fundamental Research Statistics for the Behavioral Sciences. New York: Holt, Rinehart and Winston, Inc. hal.189-197

Saputra, Perdana. (2011). Pengaruh Pendekatan Penjualan Berorientasi Konsumen Terhadap Loyalitas Konsumen Dengan Moderasi Gaya Komunikasi Konsumen Pada Pengguna Jasa Taksi Di Kota Surabaya. Skripsi. Universitas Airlangga. Surabaya.

Sugiyono. (2012). Metode Penelitian Bisnis, Alfabeta, Bandung.

Tjiptono, Fandy. (2007). Strategi Pemasaran, Yogyakarta, Andi Offset.

Ukania, Ika. (2017). Analisis Pengaruh Kualitas Produk Terhadap Loyalitas Konsumen dengan Kepuasan Konsumen Sebagai Variabel Intervening Pada Makanan Cepat Saji (Popeye), Skripsi, Jurusan Manajemen
Bisnis Syariah, Fakultas Ekonomi dan Bisnis Islam, Institut Agama Islam Negeri Surakarta, diunduh dari http://eprints.iainsurakarta.ac.id/1710/1/SKRIPSI\%20U TUH.pdf pada tanggal 16 Januari 2018. 